Review

\title{
B7-H3, a checkpoint molecule, as a target for cancer immunotherapy
}

\author{
Shuo Yang ${ }^{1,2,3}$, Wei Wei ${ }^{\circledR}$, Qi Zhao ${ }^{1,2,3 凶}$ \\ 1. Institute of Translational Medicine, Faculty of Health Sciences, University of Macau, Taipa, Macau SPR, China. \\ 2. Cancer Centre, Faculty of Health Sciences, University of Macau, Taipa, Macau SPR, China. \\ 3. Biological Imaging \& Stem Cell Core, Faculty of Health Sciences, University of Macau, Taipa, Macau SPR, China. \\ 4. Guangdong Cord Blood Bank; Guangzhou Municipality Tianhe Nuoya Bio-engineering Co. Ltd, Guangzhou, China \\ $\triangle$ Corresponding authors: Q. Zhao, Email address: qizhao@um.edu.mo; zhaoqi@alumni.cuhk.net, Tel: 853-88224824, ORCID: 0000-0002-5969-6407 or W. Wei, \\ Email: wwei@chinacord.org \\ (C) The author(s). This is an open access article distributed under the terms of the Creative Commons Attribution License (https://creativecommons.org/licenses/by/4.0/). \\ See http://ivyspring.com/terms for full terms and conditions.
}

Received: 2019.10.12; Accepted: 2020.02.05; Published: 2020.03.25

\begin{abstract}
$\mathrm{B} 7-\mathrm{H} 3$ (also known as CD276) is a newly found molecule of B7 family, which may be a promising target for cancer treatment. B7-H3 protein was demonstrated to be expressed in several kinds of tumor tissues including non-small-cell lung cancer (NSCLC) and prostate cancer. Its expression is highly associated with undesirable treatment outcomes and survival time, due to function of the immune checkpoint molecule. It was classified as either a co-stimulatory molecule for $\mathrm{T}$ cell activation or the nonimmunological role of regulating signaling pathways. Although there is still no agreed conclusion on the function of $\mathrm{B} 7-\mathrm{H} 3$, it may be a valuable target for cancer therapy. This review aims to provide a comprehensive, up-to-date summary of the advances in B7-H3 targeting approaches in cancer therapy. Although several challenges remain, $\mathrm{B} 7-\mathrm{H} 3$ offers a new therapeutic target with increased efficacy and less toxicity in future cancer treatment.
\end{abstract}

Key words: B7-H3, CD276, cancer immunotherapy, antibody, immune checkpoint

\section{Introduction}

Immunotherapy is a newly individualized treatment that activates or suppresses the immune system to amplify or diminish an immune response and has been developed rapidly for treating various forms of cancer in recent years. Immunotherapy for cancer, such as chimeric antigen receptor (CAR)-T cells, CAR-natural killer (NK) cells, PD-1 and PD-L1 inhibitor, aims to help patients' immune system fight cancer [1]. The activation of $\mathrm{T}$ cell depends on both the specific combination of $\mathrm{T}$ cell receptor (TCR) and peptide-bound major histocompatibility complex (MHC), and the interplay of co-stimulatory molecules of $\mathrm{T}$ cell with ligands on antigen presenting cells (APCs). The B7 families, peripheral membrane proteins on activated APCs, have been shown to participate in regulation of $\mathrm{T}$ cell responses (Fig. 1). Recent studies indicated that the up-regulation of inhibitory B7 molecules in the cancer microenvironment was highly related to the immune evasion of tumor [2]. As a newly identified member of the B7 family [3], B7-H3 could promote the activation of $\mathrm{T}$ cells and the proliferation of IFN- $\gamma$. In this review, we summarized research in recent years, focusing on the functional properties of $\mathrm{B} 7-\mathrm{H} 3$ and its potential role in the recent progress of cancer immunotherapy. We will also discuss the benefits, challenges, and considerations of targeting B7-H3 therapy in clinical development.

\section{B7 family}

Different B7 molecules have either positive or negative co-stimulatory signals while modulating immune cell responses (Table 1) [4, 5]. Immune checkpoints, such as PD-1, PD-L1, PD-L2, and CTLA4, are molecules holding many receptor-ligand interactions to evade the immune system and facilitate proliferation. Several monoclonal antibodies (mAbs) that block these proteins were developed to 
down-regulate the inhibitory immune response, and promote the cellular cytotoxicity of $\mathrm{T}$ cells that eliminate tumor cells [6]. Among the immune checkpoint-blocking drugs, the inhibitors targeting PD-1 or CTLA4 were successfully used for treating patients with metastatic melanoma, with improved responses and prolonged survival [7]. This success led to the development of such agents for treating a wide range of malignancies, including renal cell carcinoma (RCC) [8], NSCLC [9-11], and acute myeloid leukemia (AML) [12], which further enhanced the response rate compared to conventional treatments, and prolonged the survival time of patients.

\section{Biological function of B7-H3}

B7-H3 was found to be overexpressed among several kinds of human cancer cells and was correlated with disease deteriorations [13-19] (Table 2). B7-H3 was recognized as a co-stimulatory molecule for immune reactions such as $\mathrm{T}$ cell activation and IFN- $\gamma$ production [20]. In the presence of anti-CD3 antibody mimicking the TCR signal, human B7-H3-Ig fusion protein was found to increase the proliferation of both $\mathrm{CD}^{+}$and $\mathrm{CD} 8^{+} \mathrm{T}$ cells and enhance the cytotoxic T lymphocyte (CTL) activity in vitro. An orthotopic colon cancer model of mice was constructed by researchers who studied the mechanism of B7-H3 antitumor ability [21]. Their data suggested there was an antitumor effect of $\mathrm{B} 7-\mathrm{H} 3$ on adenocarcinoma of the colon, which could also be regarded as a promising therapy for the treatment of colon cancers. Moreover, they detected the co-stimulatory molecule role of B7-H3 in the model of colon cancers established by orthotopic injection [22]. In a study among human pancreatic cancer patients, B7-H3 was recognized as a co-stimulatory molecule that was not only abundantly expressed in pancreatic cancer but also associated with increased treatment efficacy [23]. They found that although B7-H3 expression was detectable in most examined pancreatic cancer samples, and significantly upregulated in pancreatic cancer versus normal pancreas, patients with high tumor B7-H3 levels had a significantly better postoperative prognosis than patients with low tumor B7-H3 levels.

Table 1. Different roles of B7 family members in immune cell response.

\begin{tabular}{lll}
\hline Name & Alternative name & Role in immune cell response \\
\hline B7-1 & CD80 & Activation/inhibition \\
B7-2 & CD86 & Activation/inhibition \\
B7-DC & PD-L2, CD273 & Activation/inhibition \\
B7-H1 & PD-L1, CD274 & Inhibition \\
B7-H2 & ICOSL & Activation \\
B7-H3 & CD276 & Activation/inhibition \\
B7-H4 & B7S1, B7x, Vtcn1 & Activation/inhibition \\
B7-H5 & VISTA, GI24, Dies1, PD-1H & Inhibition \\
B7-H6 & NCR3LG1 & Activation \\
B7-H7 & HHLA2 & Activation/inhibition \\
BT3.1 & BTF5, CD277, BTN3A1 & Inhibition \\
\hline
\end{tabular}

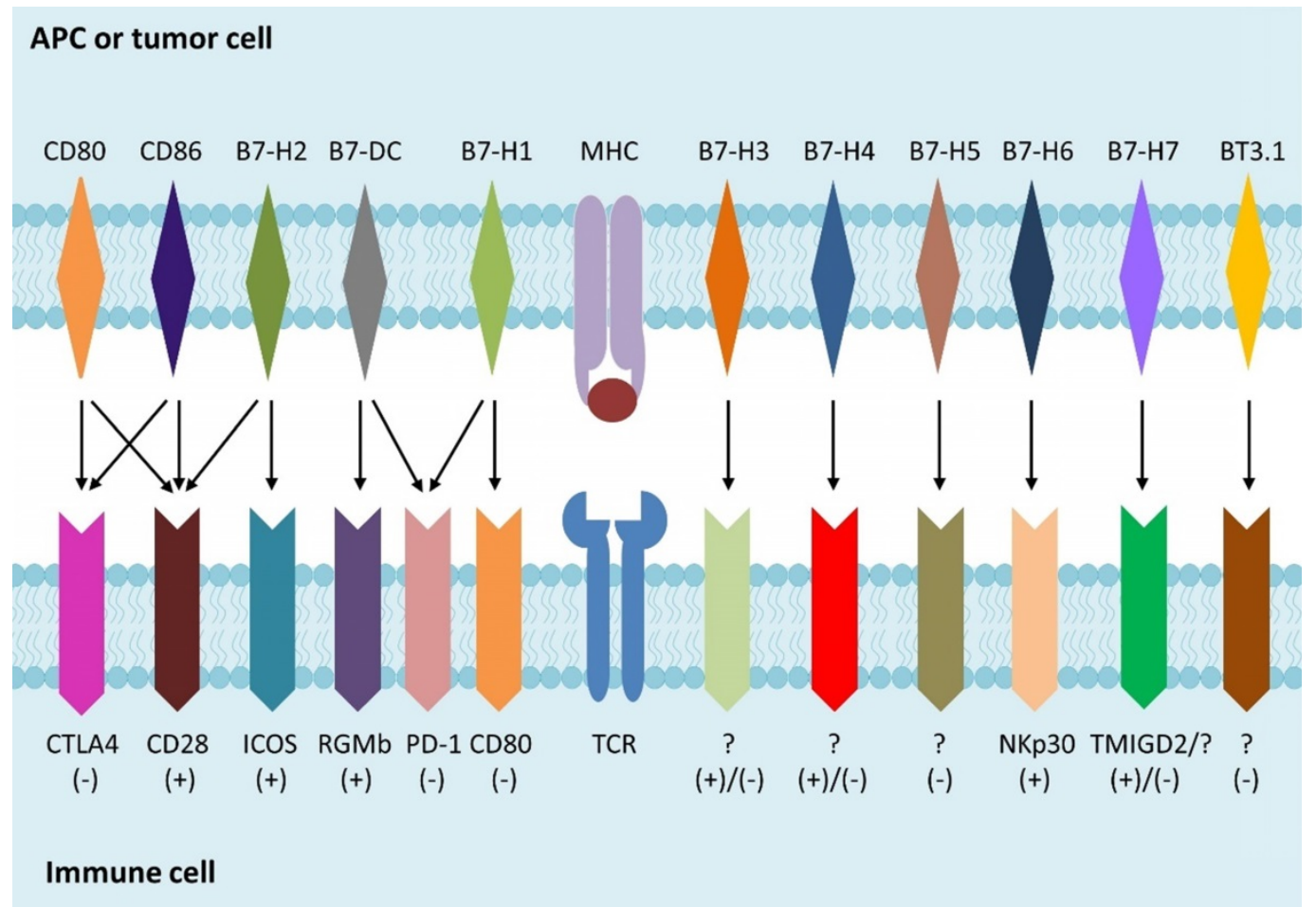

Figure 1. B7 family members and their receptors. B7 is a type of peripheral membrane protein found on activated APC. A specific antigen is presented by MHC molecules on APCs or tumor cells to TCR on T cells, to form the first signal for the activation of T cells. B7 family members as well as other co-stimulatory molecules binding to their receptors expressed on $T$ cells, which is called the second signal, is used to direct and/or fine-tune the responses of $T$ cells. 
Table 2. B7-H3 expression in multiple types of human cancers.

\begin{tabular}{|c|c|c|c|c|}
\hline Cancer type & $\begin{array}{l}\text { Case } \\
\text { number }\end{array}$ & $\begin{array}{l}\% \\
\text { Positive }\end{array}$ & Findings & Refs \\
\hline $\begin{array}{l}\text { Non-small } \\
\text { lung cancer }\end{array}$ & 82 & 74 & $\begin{array}{l}\text { B7-H3 expression was } \\
\text { correlated with ineffective } \\
\text { anti-PD-1 immunotherapy }\end{array}$ & [15] \\
\hline $\begin{array}{l}\text { Cutaneous } \\
\text { squamous cell } \\
\text { carcinoma }\end{array}$ & 66 & 85 & $\begin{array}{l}\text { Tumor B7-H3 expression was } \\
\text { higher in immunocompetent } \\
\text { patients }\end{array}$ & [16] \\
\hline $\begin{array}{l}\text { Pancreatic } \\
\text { cancer }\end{array}$ & 26 & 65.4 & $\begin{array}{l}\text { No positive cells were detected } \\
\text { in normal pancreas specimens }\end{array}$ & [17] \\
\hline $\begin{array}{l}\text { Primary } \\
\text { hepatocellular } \\
\text { carcinoma }\end{array}$ & 70 & 88.57 & $\begin{array}{l}\text { Expression of } \mathrm{B} 7-\mathrm{H} 3 \text { promoted } \\
\text { tumor progression }\end{array}$ & [18] \\
\hline $\begin{array}{l}\text { Colorectal } \\
\text { carcinoma }\end{array}$ & 117 & 96.6 & $\begin{array}{l}\text { B7-H3 expression was } \\
\text { negatively associated with } \\
\text { overall survival rate }\end{array}$ & [13] \\
\hline $\begin{array}{l}\text { Clear cell renal } \\
\text { carcinoma }\end{array}$ & 82 & 97.56 & $\begin{array}{l}\mathrm{B} 7-\mathrm{H} 3 \text { is associated with the } \\
\text { tumor-node-metastasis stage of } \\
\text { patients }\end{array}$ & [14] \\
\hline Breast cancer & 74 & 56.8 & $\begin{array}{l}\text { B7-H3 expression was mainly } \\
\text { observed in cell membrane and } \\
\text { cytoplasm }\end{array}$ & [19] \\
\hline
\end{tabular}

Recently, the inhibitory ability of B7-H3 towards $\mathrm{T}$ cell proliferation was discovered. The proliferation of both $\mathrm{CD}^{+}$and $\mathrm{CD} 8^{+} \mathrm{T}$ cells could be inhibited by B7-H3 [24]. Moreover, in synovial monocytes, the expression of surface B7-H3 was found to correlate inversely with the rheumatoid arthritis (RA) clinical parameters [25]. Another study [26] indicated that in oral squamous cell carcinoma (OSCC), larger tumor size, advanced clinical stage, and low survival rate of patients were positively associated with B7-H3 overexpression. In addition, tumor cell proliferation was suppressed when B7-H3 was blocked, and tumor growth was enhanced when B7-H3 expression was restored.

B7-H3 remains an orphan ligand, although a potential receptor, TLT-2, was detected on activated immune cells [27]. B7-H3/TLT-2 was shown to augment chemokine production and proinflammatory cytokine, by activating the phosphorylation of downstream mitogen-activated protein kinase (MAPK) p38 and NF-kappa B p65 [28]. However, similar effects were not seen in another study of both human and murine B7-H3 [29]. Thus, there is not enough evidence for TLT-2 as a receptor of B7-H3, and specific receptors capable of binding $\mathrm{B} 7-\mathrm{H} 3$ need to be conclusively identified. This may account for the contradictory co-stimulatory and co-inhibitory roles that $\mathrm{B} 7-\mathrm{H} 3$ plays in immune response.

\section{Roles of B7-H3 in tumor progression and drug resistance}

Mechanisms for the correlation between B7-H3 and tumor progression were deeply explored from immunological and non-immunological aspects. For NSCLC patients, B7-H3 and regulatory T cells (Tregs) were identified as having potential cooperative role in the immune evasion of tumor cells, and the resulting poor outcomes [30]. B7-H3 and CD14 were shown to be co-expressed in RCC tissues, which were positively associated with tumor progression, indicating that the important role B7-H3 played in angiogenesis of RCC might be influenced by $\mathrm{CD} 14^{+}$monocytes [31]. Similarly, co-expression of B7-H3 and CD133 was evidently associated with progression of $\mathrm{CD}_{133^{+}}$ colorectal cancer [32]. In colorectal carcinoma (CRC) tissues, expression of $\mathrm{B} 7-\mathrm{H} 3$ and infiltrating macrophage density were found to be positively associated, while both were negatively correlated with patients' survival rate. Since the presumed receptor of $\mathrm{B} 7-\mathrm{H} 3$ was found on activated monocytes and macrophages, these results further indicated the potential role of B7-H3 signal and macrophages in tumor progression [13]. High B7-H3 expression was found in human breast cancer tissues and may play an important role in tumor progression and invasiveness. This expression appeared to increase the ability of B7-H3 to promote secretion of the immunosuppressive cytokine IL-10 [33]. Another inhibitory molecule, immunoglobulin-like transcript 4 (ILT4), was demonstrated to increase $\mathrm{B} 7-\mathrm{H} 3$ expression through PI3K/AKT/mTOR signaling, which reduced $\mathrm{T}$ infiltrating lymphoid cells (TILs) and led to lower overall survival [34]. B7-H3 was shown to influence tumor progression by regulating the relative molecules via JAK2/STAT3 pathway in several types of cancer [35-37]. Moreover, expression of B7-H3 and tyrosine kinase receptor Tie-2 in clear cell renal cell carcinoma (ccRCC) tumor vasculature were closely related to the progression and prognosis of the disease, while ccRCC angiogenesis was possibly promoted by B7-H3 through the Tie-2 pathway [14]. Furthermore, soluble B7-H3 (sB7-H3) was reported to promote the invasion and metastasis of pancreatic carcinoma cells through the TLR4/NF-kB pathway [38].

Emerging studies have also demonstrated that B7-H3 may contribute to the resistance of anti-cancer drugs with various mechanisms. Proliferation and glycolytic capacity of metastatic melanoma cells were found to decrease when expression of $\mathrm{B} 7-\mathrm{H} 3$ was reduced or inhibited, leading to reduced resistance to chemotherapy as well as other targeted therapies [39]; this mechanism was further demonstrated to involve the inactivation of p38 MAPK signaling [40]. Similarly, glycolytic capacity was increased with the overexpression of B7-H3 in tumor cells, which induced the resistance to API-2 (triciribidine) and everolimus (RAD-001) [41]. In contrast, suppression of B7-H3 was found to improve the sensitivity of human breast cancer cell lines to chemotherapy agent paclitaxel, while overexpression of $\mathrm{B} 7-\mathrm{H} 3$ led to the 
resistance of cancer cells to the drug; this was identified as at least partially relative to interference with the Jak2/Stat3 pathway [42]. Overexpression of B7-H3 could increase the population of cancer stem cell and induce cancer cell resistance to drugs by activating MEK through major vault protein (MVP) [43]. B7-H3 can confer colorectal cancer cell resistance to 5-fluorouracil (5-FU) by increasing the expression of thymidylate synthase (TS) and activating PI3K/ Akt/TS signaling [44]. In pancreatic carcinoma cells, B7-H3 was found to induce gemcitabine resistance, at least partially due to the downregulated survivin expression [45].

\section{Targeting B7-H3 therapy}

A number of anti-B7-H3 approaches have been studied in preclinical or clinical trials. The details of several agents under clinical trials are described in this section and summarized in Table 3.

Enoblituzumab (MGA271), a humanized $\mathrm{mAb}$ targeting $\mathrm{B} 7-\mathrm{H} 3$, mediates potent antibody-dependent cellular cytotoxicity (ADCC) against a broad range of tumor types. For example, it was investigated in treating refractory B7-H3-expressing tumors such as melanoma (NCT01391143), and B7-H3-expressing neoplasms including osteosarcoma and Ewing's sarcoma (NCT02982941). Furthermore, MGA271 exhibited potent antitumor activity in xenograft models of B7-H3-expressing renal cell and bladder carcinoma. And in cynomolgus monkeys, no significant safety findings were discovered by toxicology studies [46].

Another mAb called $8 \mathrm{H} 9$, was derived from the fusion of mouse splenic lymphocytes and myeloma SP2/ 0 cells of BALB/c mice that were immunized by human neuroblastoma [47]. Since B7-H3 is both an immune inhibitory ligand and an antigen in many solid tumors, researchers humanized and affinitymatured the anti-B7-H3 mouse mAb 8H9 based on in silico modeling and affinity maturation via yeast display [48]. It was concluded that humanized $8 \mathrm{H} 9$ antibodies could regulate the inhibitory immune properties of $\mathrm{B} 7-\mathrm{H} 3$ on target tumors and affect the immune checkpoint blockade. Like other bispecific antibodies (Bi-Abs) that validated for treating various diseases $[49,50]$, activated T cell (ATC) armed with the anti-CD3 $x$ anti-B7-H3 (B7-H3Bi-Ab), had specific cytotoxic activity against tumor cells by ADCC. Compared to unarmed ATC, enhanced cytotoxic activity and cytokine secretion of B7-H3Bi-armed ATC were observed. Infusion of B7-H3Bi-armed ATC also inhibited tumor growth in vivo, and significantly improved survival [51].

Table 3. Summary of anti-B7-H3 approaches in clinic.

\begin{tabular}{|c|c|c|c|c|}
\hline Format & Drug & Tumor type & Developer & $\begin{array}{l}\text { Highest } \\
\text { trail stage }\end{array}$ \\
\hline \multirow[t]{7}{*}{$\begin{array}{l}\text { aADC and } \\
\text { ADCC }\end{array}$} & $\begin{array}{l}\text { Enoblituzumab } \\
\text { (MGA271) }\end{array}$ & $\begin{array}{l}\text { Prostate cancer, melanoma, HNSCC, NSCLC, urothelial cancer, } \\
\text { neuroblastoma, rhabdomyosarcoma, osteosarcoma, Ewing sarcoma, } \\
\text { Wilms' tumor, DSRCT or malignant solid tumors of any other histology } \\
\text { that test positive for B7-H3 }\end{array}$ & MacroGenics & Phase 2 \\
\hline & 131I-Omburtamab & $\begin{array}{l}\text { CNS/leptomeningeal metastases, DSRCT and other solid tumors } \\
\text { involving the peritoneum }\end{array}$ & Y-mAbs Therapeutics & Phase 3 \\
\hline & 177Lu-DTPA-omburtamab & Medulloblastoma & Y-mAbs Therapeutics & Phase 2 \\
\hline & 131I-8H9 & Peritoneal cancer, neuroblastoma, CNS/leptomeningeal metastases & Y-mAbs Therapeutics & Phase 3 \\
\hline & 124 I-8H9 & Brain cancer, brain stem glioma & Y-mAbs Therapeutics & Phase 1 \\
\hline & MGC018 & solid tumors & MacroGenics & Phase 1 \\
\hline & DS-7300a & Advanced solid tumor malignant & Daiichi Sankyo & phase 2 \\
\hline $\begin{array}{l}\text { Bispecific } \\
\text { antibody }\end{array}$ & $\begin{array}{l}\text { Orlotamab } \\
\text { (MGD009) }\end{array}$ & $\begin{array}{l}\text { Mesothelioma, bladder cancer, melanoma SCCHN, NSCLC, ccRCC, } \\
\text { ovarian cancer, TNBC, pancreatic cancer, prostate cancer, colon cancer, } \\
\text { soft tissue sarcoma }\end{array}$ & MacroGenics & Phase 1 \\
\hline $\begin{array}{l}\text { CAR T-cell } \\
\text { therapy }\end{array}$ & SCRI-CARB7H3 & $\begin{array}{l}\text { CNS tumor, DIPG, DMG, Ependymoma medulloblastoma, germ cell } \\
\text { tumor, atypical teratoid/rhabdoid tumor, primitive neuroectodermal } \\
\text { tumor, choroid plexus carcinoma pineoblastoma, glioma }\end{array}$ & $\begin{array}{l}\text { Seattle Children's } \\
\text { Hospital }\end{array}$ & Phase 1 \\
\hline \multirow[t]{5}{*}{$\begin{array}{l}\text { Combination } \\
\text { therapies }\end{array}$} & $\begin{array}{l}\text { MGD009 in combination with } \\
\text { MGA012 }\end{array}$ & Advanced solid tumors & MacroGenics & Phase 1 \\
\hline & $\begin{array}{l}\text { MGC018 with or without } \\
\text { MGA012 }\end{array}$ & Advanced solid tumors & MacroGenics & Phase 2 \\
\hline & $\begin{array}{l}\text { MGA271 in combination with } \\
\text { Pembrolizumab or MGA012 }\end{array}$ & Melanoma, SCCHN, NSCLC, urethelial carcinoma & MacroGenics & Phase 1 \\
\hline & $\begin{array}{l}\text { MGA271 in combination with } \\
\text { Ipilimumab }\end{array}$ & Melanoma, NSCLC & MacroGenics & Phase 1 \\
\hline & $\begin{array}{l}\text { B7-H3 CAR-T in combination } \\
\text { with Temozolomide }\end{array}$ & Recurrent glioblastoma, refractory Glioblastoma & $\begin{array}{l}\text { Second Affiliated } \\
\text { Hospital, School of } \\
\text { Medicine, Zhejiang } \\
\text { University }\end{array}$ & Phase 2 \\
\hline
\end{tabular}

aADC and ADCC refer to antibody drug conjugate (ADC) therapies drugs and drugs target B7-H3 through antibody-dependent cell-mediated cytotoxicity (ADCC) 
Researchers explored the antitumor ability of the antibody-drug conjugates (ADCs) that specifically destroyed B7-H3 positive expressing tumors, and found that established tumors and metastases were eradicated, and overall survival improved significantly, which demonstrate the anti-CD276-drug conjugates as promising reagents for highly selective broad-acting anti-cancer therapies [52]. A promising exatecan derivative (DX-8951 derivative, DXd), used for drug conjugation as DXd-ADC targeting B7-H3, showed effective antitumor efficacy as well as less adverse effects [53]. 131I-labeled anti-B7-H3 mAb (131I-4H7) had radiobiological and treatment effects on nude mice with human RCC. 131I-4H7 was markedly absorbed by RCC xenografted tumor, and the development of tumor was inhibited by 131I-4H7 significantly [54]. In addition, constructed bioconjugates targeting both $\mathrm{B} 7-\mathrm{H} 3$ and chlorin e6 have been shown to have the ability of treating NSCLC both in vitro and in vivo under the guidance of spectroscopic photoacoustic and fluorescence imaging, and could display effective tumor diagnosis and therapy as a novel approach of immunotherapy [55].

Recently, CAR-T cells that were genetically engineered to graft specific recognition ability for $\mathrm{T}$ cells were generated with $\mathrm{B} 7-\mathrm{H} 3$ as the target [56]. In this research, they explored the treatment efficacy of CAR-T cells targeting B7-H3 on pancreatic ductal adenocarcinoma, ovarian cancer, and neuroblastoma, both in vitro and in orthotopic and metastatic xenograft mouse models including patient-derived xenograft. They found that the growth of tumor could be controlled without evident toxicity. Antitumor effects of B7-H3-specific CAR-T cells were also assessed in primary glioblastoma cell lines. The specific antitumor functions of CAR-T cells were confirmed both in vitro and in vivo [57]. There is rapid development of antibody drugs and CAR-T cells that target $\mathrm{B} 7-\mathrm{H} 3$, which may be administered alone or may achieve synergistic anti-tumor effects when combined with chemotherapeutic agents or other therapeutic regimens.

\section{Conclusion}

Immunotherapy represents a new promising therapeutic approach for several cancers, and has the specific advantage of more efficacy, less side effects, and less complex processes compared to therapies such as surgery and chemotherapy. Recent research has provided strong evidence for the value of $\mathrm{B} 7-\mathrm{H} 3$ as a target in immune-based antitumor therapies, for its overexpression across several kinds of cancer cells but seldom in normal cells. Although B7-H3 was shown to exhibit inhibitory effects in modulating both
T cells and NK cells, several studies found that B7-H3 could regulate immune response towards target organs in a costimulatory manner. Until now, there is still no unified view on the receptor of the B7-H3 molecule. More research is needed to identify the mechanism of the two regulatory functions of B7-H3 and to detect its effective receptor, to further understand its regulation of immune response and develop valuable drug targets. In addition, nonimmunological roles of $\mathrm{B} 7-\mathrm{H} 3$ that associated with different proteins, may affect cancer migration, invasion, and angiogenesis by interacting with relative signaling pathways. Moreover, since B7-H3 was found broadly expressed by both tumor cells and tumor vasculature, and upregulated in clinical samples of human cancer metastases, it could be regarded as a potential marker for immune evasion of tumor cell.

Compared to other immune checkpoints, B7-H3 appears to be a unique and powerful target in cancer immunotherapy, as it not only influences innate and adaptive immunity but also regulates aggressiveness of cancer cells through various non-immunological pathways. Verification of the receptor for B7-H3 and better elucidation of B7-H3 pathway in immune response and cancer development is crucial and may help to provide rationale for therapeutic application of anti-B7-H3 agents in clinical patients. Further understanding of the role of $\mathrm{B} 7-\mathrm{H} 3$ and further preclinical and/or clinical exploration may establish this as a reasonable anti-tumor target and anti-metastatic marker.

\section{Abbreviations}

NSCLC: non-small-cell lung cancer; CAR: chimeric antigen receptor; NK: natural killer; TCR: T cell receptor; MHC: major histocompatibility complex; APC: antigen presenting cell; RCC: renal cell carcinoma; AML: acute myeloid leukemia; CTL: cytotoxic T lymphocyte; RA: rheumatoid arthritis; OSCC: oral squamous cell carcinoma; MAPK: mitogen-activated protein kinase; Treg: regulatory $\mathrm{T}$ cell; CRC: colorectal carcinoma; ILT: immunoglobulin-like transcript; ccRCC: clear cell renal cell carcinoma; sB7-H3: soluble B7-H3; MVP: major vault protein; 5-FU: 5-fluorouracil; mAb: monoclonal antibody; ADCC: antibody-dependent cellular cytotoxicity; ATC: activated T cell; Bi-Ab: bispecific antibody; ADC: antibody-drug conjugate.

\section{Acknowledgement}

This work was supported by the Science and Technology Development Fund, Macau SAR (File no. FDCT/131/2016/A3， FDCT/0015/2018/A1), the National Key R\&D Program of China (2019YFA09044 00), the Guangzhou Science and Technology Program 
(201807010004), the Multi-Year Research Grant (File no. MYRG2019-00069-FHS), Start-up Research Grand (File no.SRG2016-00082-FHS), and the intramural research program of Faculty of Health Sciences, University of Macau.

\section{Competing Interests}

The authors have declared that no competing interest exists.

\section{References}

1. Huang S, Zhao Q. Nanomedicine-combined immunotherapy for cancer. Curr Med Chem. 2019; [Epub ahead of print].

2. Zou W, Chen L. Inhibitory B7-family molecules in the tumour microenvironment. Nat Rev Immunol. 2008; 8: 467-77.

3. Zhao Q, Liu J, Yang S. Therapeutically targeting B7-H3 via chimeric antigen receptors and bispecific killer cell engagers in non-small cell lung cancer. Journal of Immunology. 2018; 200.

4. Picarda E, Ohaegbulam KC, Zang X. Molecular Pathways: Targeting B7-H3 (CD276) for Human Cancer Immunotherapy. Clin Cancer Res. 2016; 22: 3425-31.

5. Li D, Xiang S, Shen J, Xiao M, Zhao Y, Wu X, et al. Comprehensive understanding of B7 family in gastric cancer: expression profile, association with clinicopathological parameters and downstream targets. Int J Biol Sci. 2020; 16: 568-82.

6. Goodman A, Patel SP, Kurzrock R. PD-1-PD-L1 immune-checkpoint blockade in B-cell lymphomas. Nat Rev Clin Oncol. 2017; 14: 203-20.

7. Wu YL, Liang J, Zhang W, Tanaka Y, Sugiyama H. Immunotherapies: the blockade of inhibitory signals. Int J Biol Sci. 2012; 8: 1420-30.

8. Motzer RJ, Escudier B, McDermott DF, George S, Hammers HJ, Srinivas S, et al. Nivolumab versus Everolimus in Advanced Renal-Cell Carcinoma. N Engl J Med. 2015; 373: 1803-13

9. Borghaei H, Paz-Ares L, Horn L, Spigel DR, Steins M, Ready NE, et al. Nivolumab versus Docetaxel in Advanced Nonsquamous Non-Small-Cell Lung Cancer. N Engl J Med. 2015; 373: 1627-39.

10. Brahmer JR, Tykodi SS, Chow LQ, Hwu WJ, Topalian SL, Hwu P, et al. Safety and activity of anti-PD-L1 antibody in patients with advanced cancer. N Engl J Med. 2012; 366: 2455-65.

11. Garon EB, Rizvi NA, Hui R, Leighl N, Balmanoukian AS, Eder JP, et al. Pembrolizumab for the treatment of non-small-cell lung cancer. N Engl J Med. 2015; 372: 2018-28.

12. Liao D, Wang M, Liao Y, Li J, Niu T. A Review of Efficacy and Safety of Checkpoint Inhibitor for the Treatment of Acute Myeloid Leukemia. Front Pharmacol. 2019; 10: 609 .

13. Mao Y, Chen L, Wang F, Zhu D, Ge X, Hua D, et al. Cancer cell-expressed B7-H3 regulates the differentiation of tumor-associated macrophages in human colorectal carcinoma. Oncol Lett. 2017; 14: 6177-83.

14. Zhang X, Ji J, Zhang G, Fang C, Jiang F, Ma S, et al. Expression and significance of B7-H3 and Tie-2 in the tumor vasculature of clear cell renal carcinoma. Onco Targets Ther. 2017; 10: 5417-24.

15. Yonesaka K, Haratani K, Takamura S, Sakai H, Kato R, Takegawa N, et al. B7-H3 Negatively Modulates CTL-Mediated Cancer Immunity. Clin Cancer Res. 2018; 24: 2653-64.

16. Varki V, Ioffe OB, Bentzen SM, Heath J, Cellini A, Feliciano J, et al. PD-L1, B7-H3, and PD-1 expression in immunocompetent vs. immunosuppressed patients with cutaneous squamous cell carcinoma. Cancer Immunol Immunother. 2018; 67: 805-14.

17. Zhao X, Li DC, Zhu XG, Gan WJ, Li Z, Xiong F, et al. B7-H3 overexpression in pancreatic cancer promotes tumor progression. Int J Mol Med. 2013; 31: 283-91.

18. Wang F, Wang G, Liu T, Yu G, Zhang G, Luan X. B7-H3 was highly expressed in human primary hepatocellular carcinoma and promoted tumor progression. Cancer Invest. 2014; 32: 262-71.

19. Cong F, Yu H, Gao X. Expression of CD24 and B7-H3 in breast cancer and the clinical significance. Oncol Lett. 2017; 14: 7185-90.

20. Chapoval AI, Ni J, Lau JS, Wilcox RA, Flies DB, Liu D, et al. B7-H3: a costimulatory molecule for T cell activation and IFN-gamma production. Nat Immunol. 2001; 2: 269-74

21. Lupu CM, Eisenbach C, Kuefner MA, Schmidt J, Lupu AD, Stremmel W, et al. An orthotopic colon cancer model for studying the B7-H3 antitumor effect in vivo. J Gastrointest Surg. 2006; 10: 635-45.

22. Lupu CM, Eisenbach C, Lupu AD, Kuefner MA, Hoyler B, Stremmel W, et al. Adenoviral B7-H3 therapy induces tumor specific immune responses and reduces secondary metastasis in a murine model of colon cancer. Oncol Rep. 2007; $18: 745-8$.

23. Loos M, Hedderich DM, Ottenhausen M, Giese NA, Laschinger M, Esposito I, et al. Expression of the costimulatory molecule B7-H3 is associated with prolonged survival in human pancreatic cancer. BMC Cancer. 2009; 9: 463.
24. Suh WK, Gajewska BU, Okada $\mathrm{H}$, Gronski MA, Bertram EM, Dawicki W, et al. The B7 family member B7-H3 preferentially down-regulates $\mathrm{T}$ helper type 1-mediated immune responses. Nat Immunol. 2003; 4: 899-906.

25. Yoon BR, Chung YH, Yoo SJ, Kawara K, Kim J, Yoo IS, et al. Preferential Induction of the T Cell Auxiliary Signaling Molecule B7-H3 on Synovial Monocytes in Rheumatoid Arthritis. J Biol Chem. 2016; 291: 4048-57.

26. Chen JT, Chen $\mathrm{CH}, \mathrm{Ku} \mathrm{KL}$, Hsiao M, Chiang CP, Hsu TL, et al. Glycoprotein B7-H3 overexpression and aberrant glycosylation in oral cancer and immune response. Proc Natl Acad Sci U S A. 2015; 112: 13057-62.

27. Zhang G, Wang J, Kelly J, Gu G, Hou J, Zhou Y, et al. B7-H3 augments the inflammatory response and is associated with human sepsis. J Immunol. 2010; 185: 3677-84.

28. Chen X, Quinn EM, Ni H, Wang J, Blankson S, Redmond HP, et al. B7-H3 participates in the development of experimental pneumococcal meningitis by augmentation of the inflammatory response via a TLR2-dependent mechanism. J Immunol. 2012; 189: 347-55.

29. Leitner J, Klauser C, Pickl WF, Stockl J, Majdic O, Bardet AF, et al. B7-H3 is a potent inhibitor of human T-cell activation: No evidence for B7-H3 and TREML2 interaction. Eur J Immunol. 2009; 39: 1754-64.

30. Jin Y, Zhang P, Li J, Zhao J, Liu C, Yang F, et al. B7-H3 in combination with regulatory $\mathrm{T}$ cell is associated with tumor progression in primary human non-small cell lung cancer. Int J Clin Exp Pathol. 2015; 8: 13987-95.

31. Li M, Zhang G, Zhang X, Lv G, Wei X, Yuan H, et al. Overexpression of B7-H3 in CD14+ monocytes is associated with renal cell carcinoma progression. Med Oncol. 2014; 31: 349 .

32. Bin Z, Guangbo Z, Yan G, Huan Z, Desheng L, Xueguang Z. Overexpression of B7-H3 in CD133+ colorectal cancer cells is associated with cancer progression and survival in human patients. J Surg Res. 2014; 188: 396-403.

33. Liu C, Liu J, Wang J, Liu Y, Zhang F, Lin W, et al. B7-H3 expression in ductal and lobular breast cancer and its association with IL-10. Mol Med Rep. 2013; 7: 134-8.

34. Zhang P, Yu S, Li H, Liu C, Li J, Lin W, et al. ILT4 drives B7-H3 expression via $\mathrm{PI} 3 \mathrm{~K} / \mathrm{AKT} / \mathrm{mTOR}$ signalling and ILT4/B7-H3 co-expression correlates with poor prognosis in non-small cell lung cancer. FEBS Lett. 2015; 589: 2248-56.

35. Kang FB, Wang L, Jia HC, Li D, Li HJ, Zhang YG, et al. B7-H3 promotes aggression and invasion of hepatocellular carcinoma by targeting epithelial-to-mesenchymal transition via JAK2/STAT3/Slug signaling pathway. Cancer Cell Int. 2015; 15: 45.

36. Fan TF, Deng WW, Bu LL, Wu TF, Zhang WF, Sun ZJ. B7-H3 regulates migration and invasion in salivary gland adenoid cystic carcinoma via the JAK2/STAT3 signaling pathway. Am J Transl Res. 2017; 9: 1369-80.

37. Zhang J, Liu L, Han S, Li Y, Qian Q, Zhang Q, et al. B7-H3 is related to tumor progression in ovarian cancer. Oncol Rep. 2017; 38: 2426-34.

38. Xie C, Liu D, Chen Q, Yang C, Wang B, Wu H. Soluble B7-H3 promotes the invasion and metastasis of pancreatic carcinoma cells through the TLR4/NF-kappaB pathway. Sci Rep. 2016; 6: 27528.

39. Flem-Karlsen K, Tekle C, Andersson Y, Flatmark K, Fodstad O, Nunes-Xavier $\mathrm{CE}$. Immunoregulatory protein $\mathrm{B} 7-\mathrm{H} 3$ promotes growth and decreases sensitivity to therapy in metastatic melanoma cells. Pigment Cell Melanoma Res. 2017; 30: 467-76.

40. Flem-Karlsen K, Tekle C, Oyjord T, Florenes VA, Maelandsmo GM, Fodstad $\mathrm{O}$, et al. p38 MAPK activation through B7-H3-mediated DUSP10 repression promotes chemoresistance. Sci Rep-Uk. 2019; 9 .

41. Nunes-Xavier CE, Karlsen KF, Tekle C, Pedersen C, Oyjord T, Hongisto V, et al. Decreased expression of $\mathrm{B} 7-\mathrm{H} 3$ reduces the glycolytic capacity and sensitizes breast cancer cells to AKT/mTOR inhibitors. Oncotarget. 2016; 7: 6891-901.

42. Liu H, Tekle C, Chen YW, Kristian A, Zhao Y, Zhou M, et al. B7-H3 silencing increases paclitaxel sensitivity by abrogating Jak2/Stat3 phosphorylation. Mol Cancer Ther. 2011; 10: 960-71.

43. Liu Z, Zhang W, Phillips JB, Arora R, McClellan S, Li J, et al. Immunoregulatory protein $\mathrm{B} 7-\mathrm{H} 3$ regulates cancer stem cell enrichment and drug resistance through MVP-mediated MEK activation. Oncogene. 2019; 38: $88-102$.

44. Jiang B, Liu F, Liu ZH, Zhang T, Hua D. B7-H3 increases thymidylate synthase expression via the PI3k-Akt pathway. Tumor Biol. 2016; 37: 9465-72.

45. Zhao X, Zhang GB, Gan WJ, Xiong F, Li Z, Zhao H, et al. Silencing of B7-H3 increases gemcitabine sensitivity by promoting apoptosis in pancreatic carcinoma. Oncol Lett. 2013; 5: 805-12.

46. Loo D, Alderson RF, Chen FZ, Huang L, Zhang W, Gorlatov S, et al. Development of an Fc-enhanced anti-B7-H3 monoclonal antibody with potent antitumor activity. Clin Cancer Res. 2012; 18: 3834-45.

47. Modak S, Kramer K, Gultekin SH, Guo HF, Cheung NK. Monoclonal antibody $8 \mathrm{H} 9$ targets a novel cell surface antigen expressed by a wide spectrum of human solid tumors. Cancer Res. 2001; 61: 4048-54.

48. Ahmed $\mathrm{M}$, Cheng $\mathrm{M}$, Zhao $\mathrm{Q}$, Goldgur $\mathrm{Y}$, Cheal SM, Guo HF, et al Humanized Affinity-matured Monoclonal Antibody 8H9 Has Potent Antitumor Activity and Binds to FG Loop of Tumor Antigen B7-H3. J Biol Chem. 2015; 290: 30018-29.

49. Zhao Q. Bispecific Antibodies for Autoimmune and Inflammatory Diseases: Clinical Progress to Date. BioDrugs. 2020; [Epub ahead of print]

50. Chen ZZ, Wang LP, Xu TS, Wang QF, Kang LS, Zhao Q. Generation of Bispecific Antibodies by $F_{c}$ Heterodimerization and their Application. Curr Pharm Biotechno. 2016; 17: 1324-32. 
51. Ma J, Ma P, Zhao C, Xue X, Han H, Liu C, et al. B7-H3 as a promising target for cytotoxicity T cell in human cancer therapy. Oncotarget. 2016; 7: 29480-91.

52. Seaman S, Zhu Z, Saha S, Zhang XM, Yang MY, Hilton MB, et al. Eradication of Tumors through Simultaneous Ablation of CD276/B7-H3-Positive Tumor Cells and Tumor Vasculature. Cancer Cell. 2017; 31: 501-15 e8.

53. Ogitani $Y$, Abe $Y$, Iguchi $T$, Yamaguchi J, Terauchi T, Kitamura M, et al. Wide application of a novel topoisomerase I inhibitor-based drug conjugation technology. Bioorg Med Chem Lett. 2016; 26: 5069-72.

54. Wang G, Wu Z, Wang Y, Li X, Zhang G, Hou J. Therapy to target renal cell carcinoma using 131I-labeled B7-H3 monoclonal antibody. Oncotarget. 2016; 7: 24888-98.

55. Zhu LP, Liu J, Zhou GY, Ng HM, Ang IL, Ma GF, et al. Targeting immune checkpoint $\mathrm{B} 7-\mathrm{H} 3$ antibody-chlorin e6 bioconjugates for spectroscopic photoacoustic imaging and photodynamic therapy. Chem Commun. 2019; 55: 14255-8.

56. Du H, Hirabayashi K, Ahn S, Kren NP, Montgomery SA, Wang X, et al. Antitumor Responses in the Absence of Toxicity in Solid Tumors by Targeting B7-H3 via Chimeric Antigen Receptor T Cells. Cancer Cell. 2019; 35: 221-37 e8.

57. Tang $X$, Zhao S, Zhang Y, Wang Y, Zhang Z, Yang M, et al. B7-H3 as a Novel CAR-T Therapeutic Target for Glioblastoma. Mol Ther Oncolytics. 2019; 14: 279-87. 